\title{
SEZONY BIOKLIMATYCZNE MIĘDZYDOBOWYCH ZMIAN CIŚNIENIA ATMOSFERYCZNEGO W POZNANIU W DRUGIEJ POŁOWIE XX WIEKU
}

\author{
MAREK PÓŁROLNICZAK \\ Zakład Klimatologii, Instytut Geografii Fizycznej i Kształtowania Środowiska Przyrodniczego, \\ Uniwersytet im. Adama Mickiewicza w Poznaniu
}

\begin{abstract}
The article analyses the interdiurnal changes of atmospheric pressure as biometeorological mechanical stimulus that exerts influence on the human organism. It is based in the study of the daily values of the atmospheric pressure recorded in the years 1951-2000 in the area of Poznań. The following classification of inter-diurnal pressure changes is used in the research: type a, when the change is lower than $1 \mathrm{hPa}$ and is not felt by the human organism; type $\mathrm{b}$, when the range of the change is $1-4 \mathrm{hPa}$ and is felt by the human organism only to an insignificant degree; type c, the average; type d, significant (Kozłowska-Szczęsna et al. 1997). The area of study is the mutability of pressure change throughout the period of many years and finding out the patterns in these changes and the annual cycle of the average interdiurnal pressure changes and the particular stimuli. As far as the annual cycle of the interdiurnal pressure changes characterised by the occurrence of the greater changes in the colder part of the year and the smaller ones in the warmer part of the year is concerned, it has been studied by other authors, who point out that it constitutes the permanent feature of this meteorological element (Kozłowska-Szczęsna 1991; Fortuniak et al. 2000). The annual cycle has been an incentive to searching for bioclimatic seasons of the interdiunal pressure changes, which are marked out by the application of Ward procedure. The method has made it possible to take into account all types of pressure changes at a time. The average frequency of their occurrence in the period of five days, therefore a matrix of data embracing 73 pentads, each of which has four features (corresponding to the four types of pressure changes. The pentads, which have been properly grouped, create dendrite, on the basis of which the image of the annual structure of bioclimatic diurnal seasons of pressure change is made. The study shows that in the area of Poznan there are four bioclimatic seasons during the entire year and that they differ in terms of the influence on the human organism. The most significant influence in terms of the frequency of occurrence is the season $\mathrm{D}$, which takes places in the coldest time of the year. The least influential is season A due the infrequency of days when significant pressure changes take place. Between these two seasons, two transition seasons, B and $\mathrm{C}$, happen twice a year.
\end{abstract}

Keywords: Poznań, daily changes in atmospheric pressure, bioclimatic seasons

\section{WSTĘP}

W biometeorologii międzydobowe zmiany ciśnienia atmosferycznego zaliczane są do bodźców fizycznych $\mathrm{z}$ wiatrem tworzących grupę bodźców mechanicznych. Uważa się, że ich działanie na organizm człowieka odbywa się głównie poprzez układ nerwowy, którego odpowiedź, w zależności od stopnia nasilenia bodźca, powoduje różne reakcje organizmu. W przypadku słabego i umiarkowanego bodźca nie dochodzi do przeciążenia ustroju, które ma miejsce, kiedy 
działa bodziec silny. Wynika stąd, że najbardziej niekorzystnym bodźcem ze strony międzydobowych zmian ciśnienia są jego duże zmiany z dnia na dzień. Niekorzystne działanie należy też przypisać braku lub słabym bodźcom, gdyż powodują wydelikacenie, a nawet zupełną utratę naturalnego przystosowania organizmu do odbierania bodźców. Zatem, jedynie umiarkowane zmiany ciśnienia występujące $z$ dnia na dzień, utrzymując ustrój w dobrej kondycji, prowadzą do jego zahartowania, przez co stanowią korzystny bodziec mechaniczny. Należy również wspomnieć, że dla meteoropatów, czyli osób w szczególny sposób odczuwających bodźce mechaniczne (także inne bodźce atmosferyczne), nasilenie działającego bodźca oraz stopień odczucia tego nasilenia pozostają jeszcze w znacznie bardziej złożonym związku, gdyż nawet słabe działanie kilku bodźców jednocześnie może prowadzić do ich wzmocnienia i obciążenia ustroju. Istotne znaczenie $\mathrm{w}$ odbieraniu bodźców atmosferycznych mają również tzw. czynniki osobnicze, czyli: stan zdrowia, wiek, płeć, przebyte choroby itd. Oznacza to, że taki sam bodziec mechaniczny, działając $\mathrm{z}$ określonym natężeniem na różne organizmy, może wywoływać odmienny stopień ich obciążenia. $Z$ powyższych rozważań wyłania się obraz dość złożonych zależności, co niewątpliwie powoduje znaczne trudności w ich ocenie.

W literaturze przedmiotu przyjmuje się najczęściej, że silny bodziec mechaniczny to zmiana $z$ dnia na dzień średniej dobowej wartości ciśnienia atmosferycznego przekraczająca $8 \mathrm{hPa}$, zmiana od 5 do $8 \mathrm{hPa}$ jest uznawana za umiarkowana, natomiast od 1 do $4 \mathrm{hPa}$ za słabą (Kozłowska-Szczęsna i in. 1997).

Przeglądając dotychczasowe piśmiennictwo dotyczące wpływu zmian ciśnienia na ustrój człowieka, można ogólnie podzielić je na obserwacje dokonywane poprzez bezpośrednie korelowanie zmian ciśnienia i efektu przez nie wywoływanego w ustroju lub obserwacje pośrednie, gdzie zmiana ciśnienia jest jednym z głównych elementów, lecz nie jest brana pod uwagę w odosobnieniu (np. w badaniach nad frontami atmosferycznymi, zmianami mas powietrza, przechodzeniem układów barycznych i burz). $\mathrm{Z}$ tego powodu często istnieją duże trudność w ocenianiu niektórych doniesień, a wiele obserwacji potrzebuje jeszcze rzetelnego potwierdzenia. Jednak $\mathrm{z}$ badań wynika, że międzydobowe zmiany ciśnienia atmosferycznego mogą wpływać patogennie zarówno na funkcje ustroju, jak i psychikę człowieka. Najczęstsze doniesienia mówią o związkach zmian ciśnienia z: chorobami układu krążenia, zawałami serca, bólami głowy (szczególnie migrenowymi), chorobami reumatycznymi, wrzodowymi, zaburzeniami psychicznymi i wieloma innymi. W wielu przypadkach można zaobserwowano sezonowość występowania chorób, polegająca na cyklicznym pojawianiu się w ciagu roku okresów częstszych lub rzadszych zachorowań. 


\section{CEL I METODA BADAŃ}

Za cel opracowania przyjęto ocenę zmienności ciśnienia atmosferycznego $\mathrm{z}$ dnia na dzień, a także podjęto próbę wyznaczenia i wstępnej analizy sezonów bioklimatycznych międzydobowych zmian ciśnienia atmosferycznego.

Do zrealizowania celu posłużono się codziennymi wartościami średniego dobowego ciśnienia atmosferycznego na poziomie rzeczywistym za lata 1951-2000, zanotowanymi na stacji meteorologicznej Poznań-Ławica. Na podstawie tego zbioru danych wyliczono codzienne wartości międzydobowych zmian ciśnienia atmosferycznego i zaszeregowano je do odpowiedniego typu zmiany według klasyfikacji stosowanej w badaniach biometeorologicznych. Uznano dodatkowo, że brak zmiany lub zmianę poniżej $1 \mathrm{hPa}$ (brak odczucia zmiany przez organizm człowieka) oznacza się jako typ $a$, natomiast dalsze typy tej klasyfikacji to: typ $b$ - zmiana 1-4 hPa (słabe odczucie zmiany), typ $c$ - zmiana 5-8 hPa (umiarkowane odczucie) oraz typ $d$-zmiana powyżej $8 \mathrm{hPa}$ (silne odczucie zmiany).

W dalszej kolejności, posługując się powyższą klasyfikacją, na podstawie danych za lata 1951-2000 obliczono średnie częstości występowania poszczególnych typów zmiany ciśnienia w każdym dniu roku. Przebieg roczny częstości dni ze wspomnianymi typami zmiany ciśnienia wykazuje wyraźną cykliczność roczna, dlatego na podstawie tego elementu postanowiono wyznaczyć sezony bioklimatyczne międzydobowych zmian ciśnienia.

W celu rozwiązania podjętego zagadnienia odwołano się do metod taksonomicznych, które pozwalają na równoczesne uwzględnienie kilku elementów oraz uznawane są za względnie najbardziej precyzyjne i obiektywne (Chojnicki, Czyż 1973; Parysek 1982). Zastosowano hierarchiczne grupowanie obiektów wielocechowych na podstawie odległości euklidesowych, czyli geometrycznych odległości w przestrzeni wielowymiarowej, w której wymiarami są kolejne cechy (Bednorz i in. 2001). Wykorzystano metodę opartą na minimalnej wariancji, znanąjako metoda Warda, której istotą jest łączenie rozpatrywanych obiektów w skupienia.

Na pierwszym etapie postępowania oblicza się odległości euklidesowe pomiędzy każdą parą badanych jednostek i w ten sposób ustala się ich ,położenie” w przestrzeni wielowymiarowej. Odległości pomiędzy badanymi jednostkami są odległościami taksonomicznymi, czyli miarą stopnia zróżnicowania badanych jednostek z punktu widzenia uwzględnianych cech tych jednostek. Odległość taksonomiczna wyrażona jest tutaj matematyczną miarą podobieństwa wyliczoną na podstawie wzoru na odległość euklidesową:

$$
D x, y=\left\{\sum i(x i-y i) 2\right\} 0,5
$$

gdzie:

$x$ i $y \quad-\quad$ obiekty, pomiędzy którymi obliczana jest odległość, $i \quad-\quad$ numer cechy charakteryzujący dany obiekt. 
Początkowo obiekty są osobnymi skupieniami, a liczba skupień zmniejsza się w kolejnych krokach postępowania poprzez łączenie (aglomerację) obiektów w grupy wyższego rzędu. Łączone są dwa skupienia A i B, które tworząc jedno skupienie, zapewnią minimum sumy kwadratów odchyleń wszystkich obiektów od środka ciężkości nowo utworzonego skupienia (AB). Po każdym kroku liczebność zbioru zmniejsza się o jeden obiekt, a procedura łączenia jest prowadzona aż do momentu otrzymania jednego skupienia obejmującego wszystkie obiekty analizowanego wzoru. W wyniku tak przeprowadzonej procedury uzyskuje się dendryt, który przedstawia relacje typologiczne pomiędzy badanymi jednostkami, lecz jeszcze ich nie klasyfikuje. Dopiero podział dendrytu na części wyznacza grupy jednostek (klasy typologiczne) obejmujące w określonym stopniu jednorodne jednostki. Podziału takiego dokonuje się za pomocą wskaźników statystycznych, które wyznaczają tzw. odległość krytyczną. Według tego postępowania rozdziela się zbiór na dwa podzbiory, jeżeli najkrótsza odległość między parą punktów należących do mających powstać podzbiorów jest większa niż wspomniana odległość krytyczna (Woś 1977; Tamulewicz 1982; Kolendowicz 1998; Gabała 2004; Jarzyna 2004).

Zgodnie z opisaną procedurą dokonano na kilku etapach kolejnych obliczeń mających ukazać strukturę sezonową międzydobowych zmian ciśnienia atmosferycznego. Przygotowana do podziału macierz danych składała się z 73 pentad, które stanowią grupowane obiekty i czterech cech dla każdego obiektu. Za cechy, według których grupowano obiekty, przyjęte zostały częstości występowania dni z charakterystyczną międzydobową zmianą średniego dobowego ciśnienia atmosferycznego klasyfikowane w przedziałach zmiany, które uznano za typy $(a, b, c, d)$ stanowiące wskaźnik bioklimatyczny. Tak przygotowana macierz danych została przeliczona w programie Statistica zgodnie z opisanymi założeniami. Zastosowano metodę Warda i otrzymano dendrogram połączeń poszczególnych jednostek. W dalszej kolejności należało zdecydować, w którym miejscu należy przeciąć gałęzie dendrogramu w taki sposób, aby dokonać podziału całej zbiorowości na grupy. Przecięcia dendrogramu dokonano na podstawie odległości krytycznej obliczonej na podstawie średnich odległości i odchyleń standardowych w dendrogramie, czyli wykorzystując własności rozkładu normalnego. Odległość krytyczną obliczono ze wzoru:

$$
D_{k}=d_{i k}+2 / 3 S d
$$

gdzie:

$D_{k} \quad-\quad$ odległość krytyczna pomiędzy jednostkami (pentadami),

$d_{i} \quad-\quad$ średnia odległość w dendrogramie,

Sd _ - odchylenie standardowe odległości w dendrogramie. 
Po oznaczeniu odległości krytycznej na dendrogramie powstały cztery grupy pentad, jednak w niektórych przypadkach zdarzały się pentady należące (według kryterium czasowego) do innej grupy, dlatego koniecznym było przyjęcie arbitralnego założenia: do ustanowienia osobnego okresu musi zaistnieć grupa złożona $\mathrm{z}$ co najmniej trzech pentad. $Z$ tej przyczyny w przypadkach pojedynczego lub podwójnego wystapienia „niedopasowanych” pentad były one dołączane do najbliższych sąsiednich grup. Uporządkowane grupy: A, B, C i D tworzą sezony bioklimatyczne międzydobowych zmian ciśnienia.

Zanim przyjęto wspomnianą wielkość założenia (trzy pentady), testowano również założenia o większej dokładności podziału (dwie pentady), które dawało bardzo mocno zróżnicowany i mało czytelny obraz struktury sezonowej zmian ciśnienia atmosferycznego. Dopiero przyjęcie założenia, że sezon mogą tworzyć grupy złożone z co najmniej trzech pentad, przyniosło zadowalający efekt.

\section{WYNIKI BADAŃ}

Najwyższa absolutna międzydobowa zmiana średniego dobowego ciśnienia atmosferycznego w Poznaniu w latach 1951-2000 wystapiła 8 stycznia $1958 \mathrm{r}$. i wyniosła $29,6 \mathrm{hPa}$, natomiast średnia roczna wartość dla tego okresu to 4,4 hPa.

Przebieg średnich międzydobowych zmian ciśnienia atmosferycznego w Poznaniu wykazuje cykliczność o okresie rocznym, która objawia się większymi zmianami ciśnienia w chłodniejszej (z maksimum w zimie) i mniejszymi w cieplejszej (z minimum w lecie) części roku. Inną charakterystyczną cechą rocznego cyklu międzydobowych zmian ciśnienia jest występowanie w chłodniejszej części roku dużego zróżnicowania wartości zmiany w krótkich okresach, na przykład z dnia na dzień, podczas gdy w cieplejszej części roku zróżnicowanie to jest wyraźnie mniejsze (ryc. 1). Jak wykazują również inni autorzy, wskazane charakterystyki rocznego przebiegu ciśnienia atmosferycznego dla umiarkowanych szerokości geograficznych są jego trwałą cechą (Kozłowska-Szczęsna 1991; Fortuniak i in. 2000).

Opisując międzydobowe zmiany ciśnienia atmosferycznego na podstawie średniej ruchomej 17-dniowej, można wykazać kilka charakterystycznych cech jej przebiegu rocznego (ryc. 1). Od stycznia, kiedy notuje się jedne z najwyższych w roku wartości międzydobowych zmian ciśnienia, do połowy lutego krzywa częstości przebiega na poziomie nieznacznie poniżej $6 \mathrm{hPa}$. Następnie zaznacza się wyraźny spadek krzywej osiagający w ciagu kilku dni poziom $5 \mathrm{hPa}$, na którym przebiega przez pierwszą dekadę marca. W kolejnym spadku wartości krzywa osiaga poziom nieznacznie poniżej $5 \mathrm{hPa}$, z którego systematycznie obniża swój przebieg, aby w trzeciej dekadzie kwietnia przeciąć wartość średnią $\mathrm{z}$ wielolecia $(4,4 \mathrm{hPa}$ - linia prosta na wykresie). W najprostszym podziale roku 


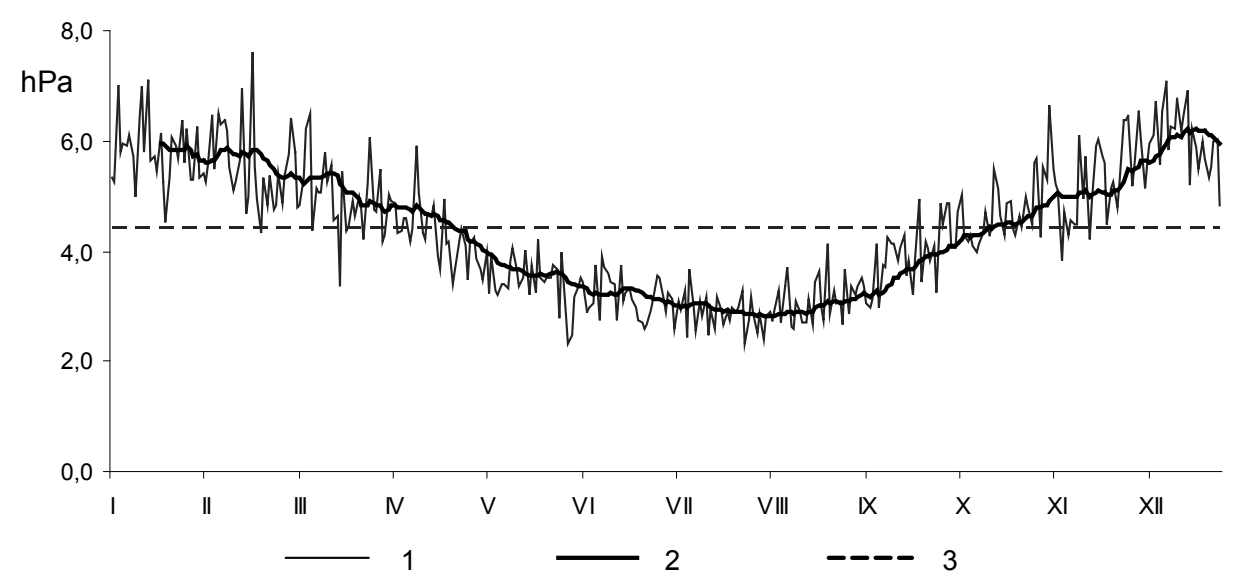

Ryc. 1. Poznań - średnie międzydobowe zmiany ciśnienia atmosferycznego (linia cienka) wygładzone średnią ruchomą 17-dniową (linia pogrubiona) oraz średnia roczna w wieloleciu 1951-2000 (linia przerywana)

Fig. 1. Poznań - the average interdiurnal pattern of the atmospheric pressure changes (fine line), the movable average of the 17 days (bold line), the annual average form the years 1951-2000 (dotted line)

na okresy międzydobowych zmian ciśnienia moment przejścia krzywej przez wartość średnią wieloletnią może być traktowany jako początek okresu mniejszej bodźcowości działania międzydobowych zmian ciśnienia atmosferycznego. Jego początek przypada na trzecią dekadę kwietnia, natomiast koniec następuje pod koniec pierwszej dekady października - z ponownym przekroczeniem przez krzywą zmian ciśnienia wartości średniej wieloletniej. W tym okresie międzydobowe zmiany ciśnienia wykazują najniższe roczne wartości z minimum na poziomie około 3,0 hPa notowanym na przełomie lipca i sierpnia. Po minimum rocznym następuje równomierny wzrost biegu krzywej, która w pierwszej dekadzie października przecina ponownie poziom średniej rocznej i rozpoczyna drugi okres $\mathrm{w}$ roku z większymi międzydobowymi zmianami ciśnienia, który trwa do trzeciej dekady kwietnia. Od początku tego okresu do połowy listopada wartości osiagają średnie na poziomie 4-5 hPa. Później następuje okres szybkiego ich wzrostu aż do grudniowego maksimum rocznego na poziomie $6,2 \mathrm{hPa}$. W okresie występowania wyższych od średniej rocznej wartości międzydobowych zmian ciśnienia notuje się również znacznie większą zmienność tych wartości z dnia na dzień w porównaniu do występującej w okresie międzydobowych zmian ciśnienia poniżej średniej rocznej.

Na cykl roczny średnich międzydobowych zmian ciśnienia składają się cykle występowania dni z charakterystycznymi wielkościami zmiany ciśnienia z dnia na dzień, czyli typy międzydobowych zmian ciśnienia $a, b, c$ i $d$. 
Dni ze zmianą ciśnienia typu a (zmiana poniżej $1 \mathrm{hPa}$, brak odczucia przez organizm człowieka) pojawiają się z częstością roczną 7,4\% (ryc. 2). Ich cyk1 roczny wskazuje na większe częstości w najcieplejszym i mniejsze w najchłodniejszym okresie roku. Maksymalnych częstości tych dni można spodziewać się w lipcu, kiedy osiagają średnio $11-12 \%$, natomiast najmniej jest ich na przełomie roku (ok. 4\%). W ciągu roku omawiane dni charakteryzują się dużą zmiennością w krótkim czasie, co wyraźnie pokazują wartości średnie dobowe.

Dni z międzydobową zmianą ciśnienia atmosferycznego typu $b$ (zmiana 1-4 hPa - słabe odczucie zmiany) pojawiają się w Poznaniu ze średnią częstością roczną 53,7\% i są najczęściej notowane spośród wszystkich omawianych typów. Roczny przebieg częstości dni tego typu wykazuje charakterystyczny rytm (ryc. 3). Od początku roku krzywa częstości (średnia ruchoma 17-dniowa) przebiega poniżej średniej rocznej, osiagając poziom 43\%, który jest jednocześnie najniższym w roku. Stosunkowo równomierny wzrost częstości tych dni w ciagu pierwszych czterech miesięcy roku doprowadza do przekroczenia średniej rocznej częstości i dalej do osiagnnięcia maksimum rocznego w pierwszych dniach sierpnia (70\%). Dalszy cykl roczny wykazuje równomierny spadek częstości omawianych dni aż do wartości średniej rocznej i dalej do grudniowych wartości na poziomie nieco ponad 40\%. Dni z międzydobową zmianą ciśnienia atmosferycznego typu $c$ (zmiana 5-8 hPa - umiarkowane odczucie zmiany) pojawiają się z częstością roczną $25,3 \%$ (ryc. 4). Ich cykl roczny można podzielić

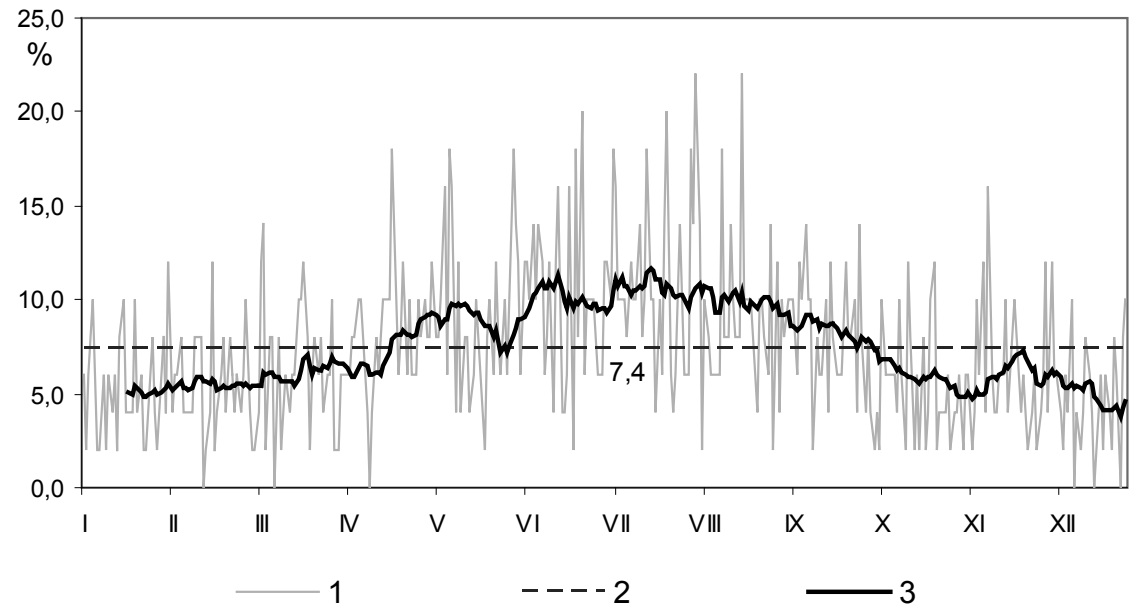

Ryc. 2. Poznań - częstość występowania dni z międzydobową zmianą ciśnienia typu $a$ (brak odczucia zmiany). Wartości średnie codzienne (1), średnia wieloletnia (2) oraz średnia ruchoma 17-dniowa (3). Dane z lat 1951-2000 w procentach

Fig. 2. Poznan - the frequency of occurrence of the days with the interdiurnal pressure changes of type $a$ (no change felt). The average daily changes (1), the perennial average (2), and the movable average lasting 17 days (3). The data embrace the period of 1951-2000 


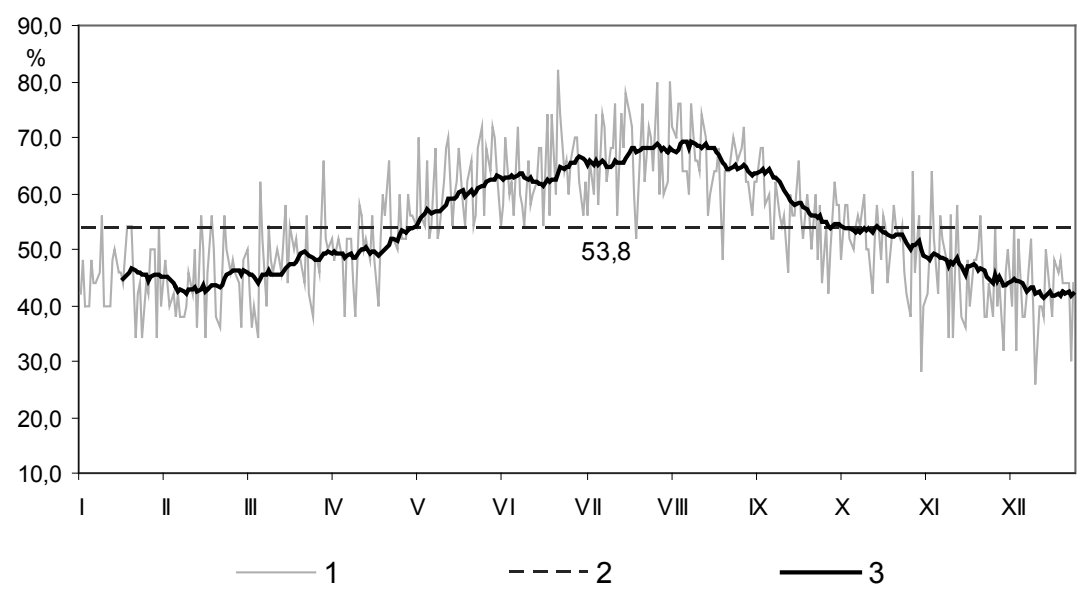

Ryc. 3. Poznań - częstość występowania dni z międzydobową zmianą ciśnienia typu $b$ (słabe odczucie zmiany). Wartości średnie codzienne (1), średnia wieloletnia (2) oraz średnia ruchoma 17-dniowa (3). Dane z lat 1951-2000 w procentach

Fig. 3. Poznan - the frequency of occurrence of the days with the interdiurnal change of type $b$ (the change only slightly felt by the human body). The average daily changes (1), the perennial average (2), and the movable average lasting 17 days (3). The data embrace the period of 1951-2000

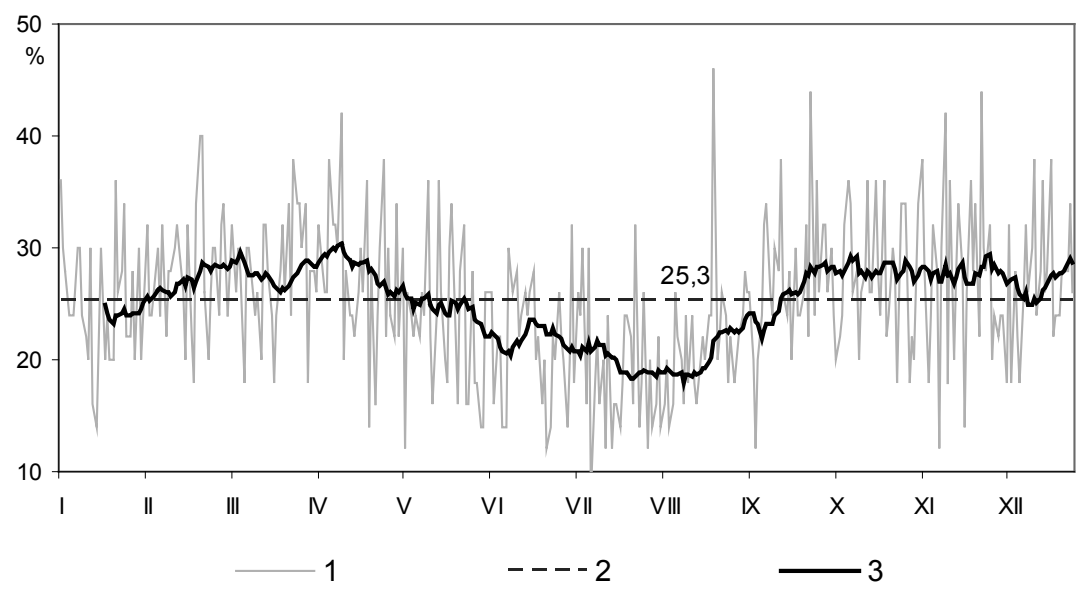

Ryc. 4. Poznań - częstość występowania dni z międzydobową zmianą ciśnienia typu $c$ (umiarkowane odczucie zmiany). Wartości średnie codzienne (1), średnia wieloletnia (2) oraz średnia ruchoma 17-dniowa (3). Dane z lat 1951-2000 w procentach

Fig. 4. Poznan - the frequency of occurence of the days with the interdiurnal pressure change of type $c$ (the change felt to some extent). The average daily changes (1), the perennial average (2), and the movable average lasting 17 days (3). The data embrace the period of 1951-2000 
na dwa okresy: z częstościami poniżej średniej rocznej - od początku maja do drugiej dekady września, i częstościami przeważnie ponad średnią wieloletnią - w pozostałym okresie. Najczęściej dni z umiarkowanym odczuciem zmiany ciśnienia pojawiają się na początku kwietnia (30\%), natomiast najrzadziej, na poziomie $19 \%$, występują od połowy lipca do połowy sierpnia.

Dni z międzydobową zmianą ciśnienia atmosferycznego typu $d$ (zmiana powyżej $8 \mathrm{hPa}$ - silne odczucie zmiany ciśnienia) występują ze średnią roczną częstością $13,4 \%$ (ryc. 5). Wykazują bardzo wyraźny cyk1 roczny z największymi częstościami zimą (maksimum w grudniu 28\%) i najmniejszymi latem (minimum w lipcu i sierpniu na poziomie 2-3\%). Na podstawie średniej rocznej częstości tych dni można również wskazać dwa charakterystyczne okresy w roku: pierwszy - od trzeciej dekady kwietnia do trzeciej dekady października, drugi - w pozostałych dniach, głównie chłodniejszej części roku.

Zanalizy wielolecia 1951-2000 wynika, że największa coroczna zmienność dni z przyjętymi typami międzydobowych zmian ciśnienia występuje w typie $a$ i $b$. W obu przypadkach współczynniki zmienności wskazują około $20 \%$ (tab. 1). W przypadku pozostałych typów zmiany ciśnienia współczynniki zmienności wykazują ich znacznie większą coroczną powtarzalność. Z kolei badanie trendów rocznych liczby dni z rozważanymi typami zmian ciśnienia wykazało bardzo niewielkie lub niemal zupełny brak trendów w typie $a$ i $c$ (ryc. 6 i 8), a także znaczne trendy w pozostałych typach (ryc. $7 \mathrm{i}$ ). W typie $b$ zanotowano ujemny

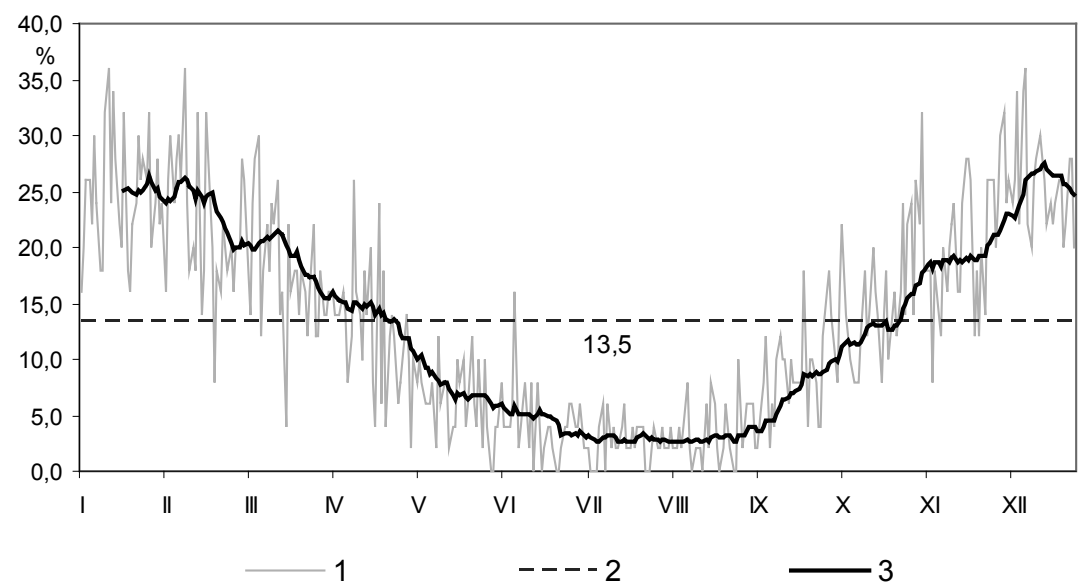

Ryc. 5. Poznań - częstość występowania dni z międzydobową zmianą ciśnienia typu $d$ (silne odczucie zmiany). Wartości średnie codzienne (1), średnia wieloletnia (2) oraz średnia ruchoma 17-dniowa (3). Dane z lat 1951-2000 w procentach

Fig. 5. Poznan - the frequency of occurrence of the days with the interdiurnal pressure change of type $d$ (the change felt to a high degree). The average daily changes (1), the perennial average (2), and the movable average lasting 17 days (3). The data embrace the period of 1951-2000 
Tabela 1. Współczynniki zmienności (1) liczby dni z typami zmian ciśnienia $(a, b, c, d)$ oraz ich średnie (2), najmniejsze (3) i największe (4) liczby w roku z lat 1951-2000

Table 1. Variability coefficient (1) of the number of days with the particular type of pressure change ( $a, b, c, d)$ and the average (2), the smallest (3) and the greatest (4) number of the days in the year, calculated for each year from the period of 1951-2000

\begin{tabular}{ccccc}
\hline & $a$ & $b$ & $c$ & $d$ \\
\hline 1 & 19,5 & 5,6 & 8,8 & 19,5 \\
2 & 27 & 197 & 92 & 49 \\
3 & 15 & 178 & 75 & 31 \\
4 & 44 & 228 & 107 & 68 \\
\hline
\end{tabular}

trend na poziomie około 16 dni na 100 lat, natomiast w typie $d$ zauważono wyraźny wzrost liczby dni, wynoszący blisko 14 dni w okresie 100-letnim. Jednakże wyznaczone trendy nie są istotne statystycznie.

Z powyższej analizy wynika jednoznacznie, że w ciagu roku bodźcowe działanie międzydobowych zmian ciśnienia wykazuje cykliczność o okresie rocznym; w znacznym stopniu zróżnicowaną, biorąc pod uwagę częstość występowania poszczególnych rodzajów bodźców. Wynika stąd, że prosty podział na

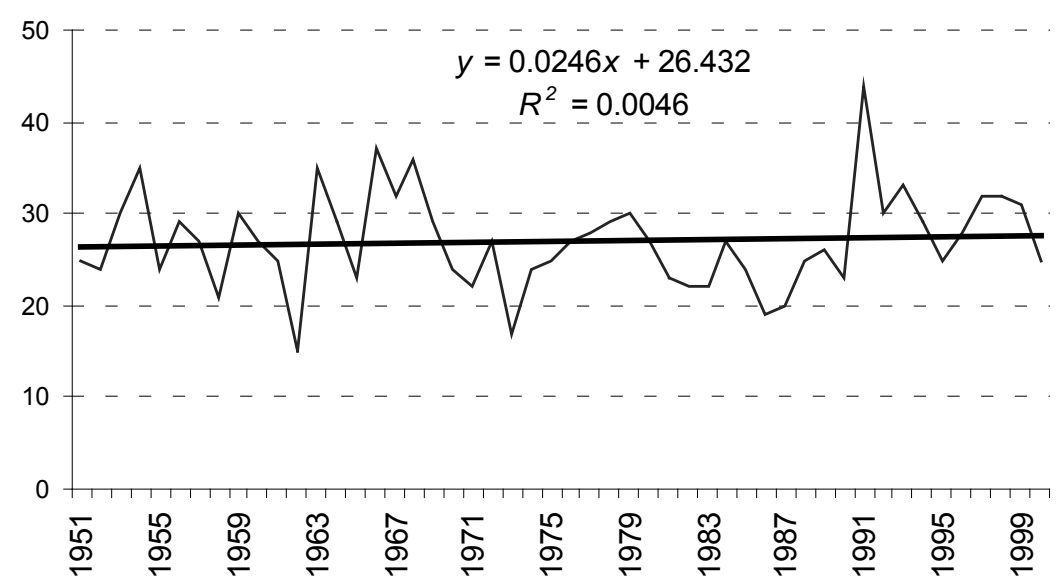

Ryc. 6. Wieloletni przebieg rocznej liczby dni z międzydobową zmianą ciśnienia atmosferycznego typu $a(<1 \mathrm{hPa})$ w Poznaniu z linią trendu. Dane z lat 1951-2000

Fig. 6. The perennial progress of the annual number of the days with the interdiurnal pressure change of type $a(<1 \mathrm{hPa})$ in Poznan and the line of the trend. Data from the years 1951-2000 


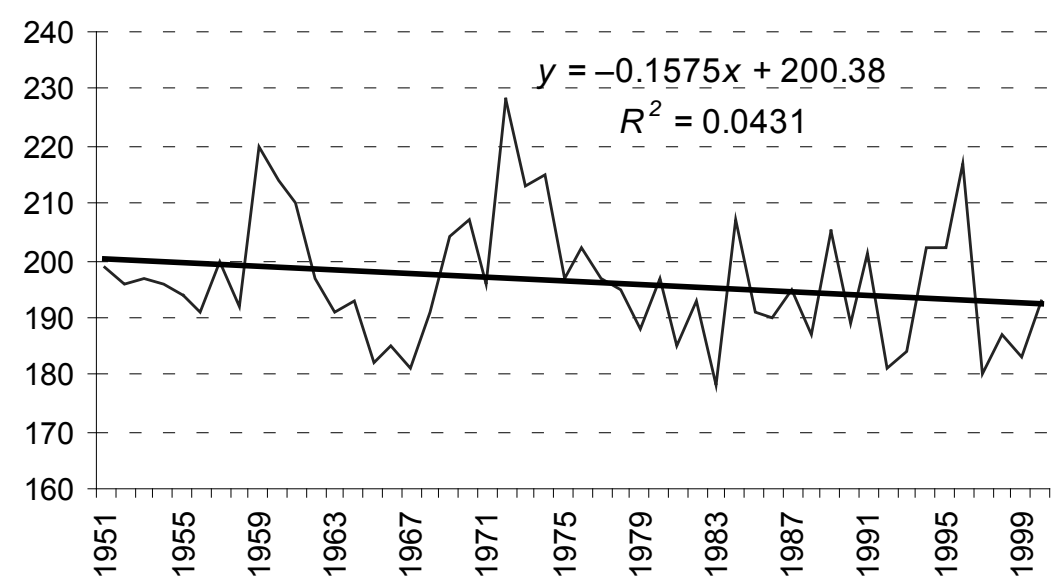

Ryc. 7. Wieloletni przebieg rocznej liczby dni z międzydobową zmianą ciśnienia atmosferycznego typu $b(1-4 \mathrm{hPa}) \mathrm{w}$ Poznaniu z linią trendu. Dane z lat $1951-2000$

Fig. 7. The perennial progress of the annual number of the days with the interdiurnal pressure change of type $b(1-4 \mathrm{hPa})$ in Poznan and the line of the trend. Data from the years $1951-2000$

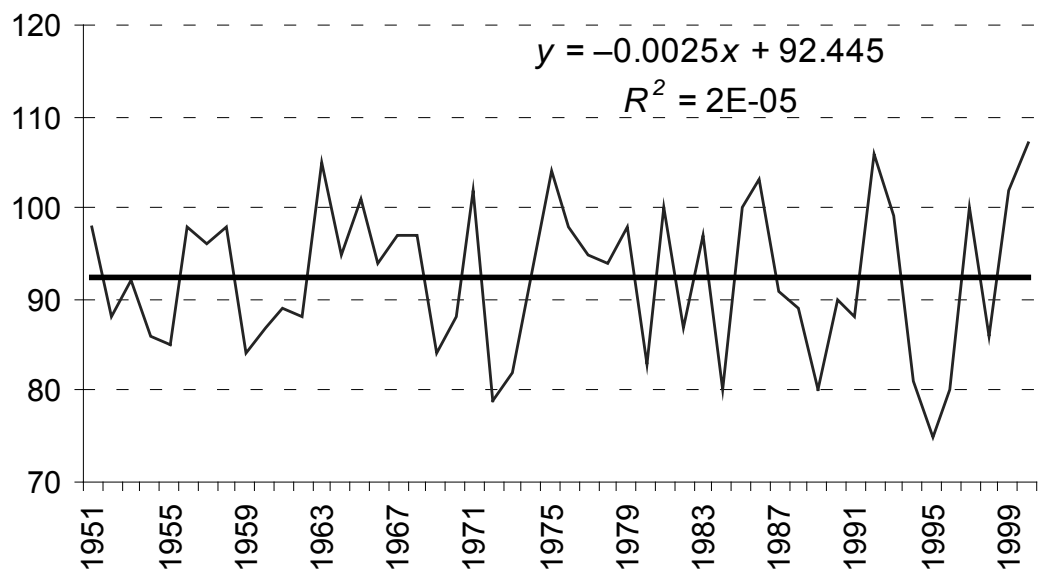

Ryc. 8. Wieloletni przebieg rocznej liczby dni z międzydobową zmianą ciśnienia atmosferycznego typu $c(5-8 \mathrm{hPa})$ w Poznaniu z linią trendu. Dane z lat 1951-2000

Fig. 8. The perennial progress of the annual number of the days with the interdiurnal pressure change of type $c(5-8 \mathrm{hPa})$ in Poznan and the line of the trend. Data from the years 1951-2000 


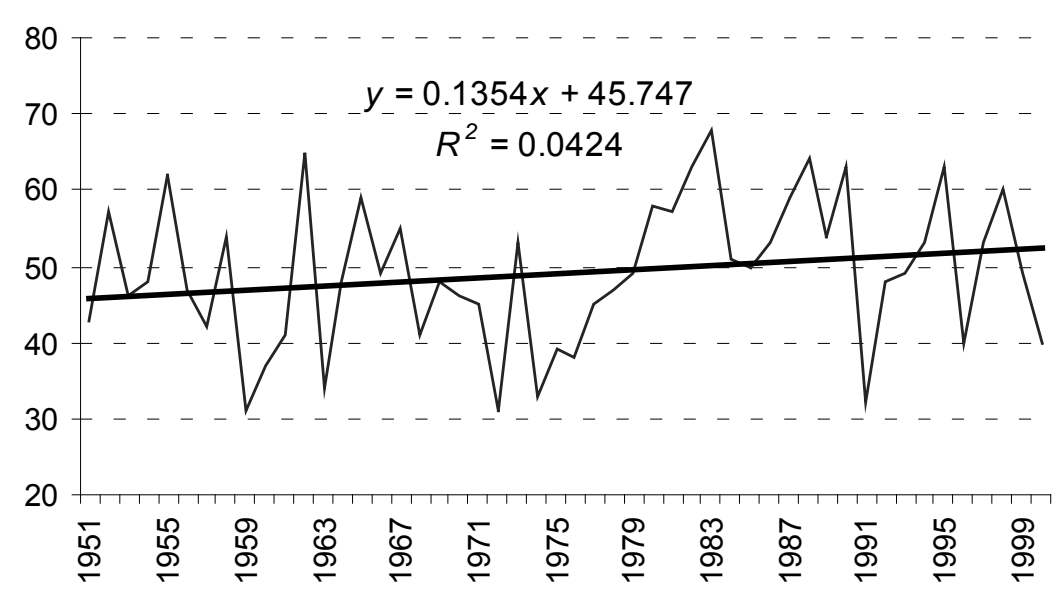

Ryc. 9. Wieloletni przebieg rocznej liczby dni z międzydobową zmianą ciśnienia atmosferycznego typu $d(>8 \mathrm{hPa})$ w Poznaniu z linią trendu. Dane z lat 1951-2000

Fig. 9. The perennial progress of the annual number of the days with the interdiurnal pressure change of type $d(>8 \mathrm{hPa})$ in Poznan and the line of the trend. Data from the years 1951-2000

okresy ze średnią międzydobową zmianą ciśnienia powyżej lub poniżej średniej rocznej jest niedokładny i nie opisuje wystarczająco zróżnicowania bodźców mechanicznych w ciągu roku. Dlatego w obecnym opracowaniu przyjęto sposób dzielenia roku na sezony na podstawie częstości występowania wszystkich typów zmiany ciśnienia, które opisują stopień nasilenia bodźców mechanicznych. Zastosowana metoda pozwala wziąć pod uwagę jednocześnie cały zakres omawianych bodźców i na podstawie ich częstości oraz relacji pomiędzy tymi częstościami umożliwia wyznaczenie okresów o możliwie podobnych (wewnątrz jednego sezonu) i możliwie różnych (porównując różne sezony) warunkach.

\section{SEZONY BIOKLIMATYCZNE MIĘDZYDOBOWYCH ZMIAN CIŚNIENIA ATMOSFERYCZNEGO}

Zgodnie z obecnym stanem wiedzy warunki bioklimatyczne ocenia się na podstawie kompleksowego działania różnych czynników atmosferycznych, które poprzez wystąpienie w tym samym momencie mogą wzajemnie wzmacniać swoją bodźcowość. Często jednak ze względu na brak informacji lub dużą złożoność wszystkich czynników wpływających na bodźcowość atmosfery, prawidłowa ocena warunków bioklimatycznych może być trudna. W takich sytuacjach 
międzydobowe zmiany ciśnienia atmosferycznego, jako wskaźnik biometeorologiczny, w wartościach którego zawarte są pośrednio zmiany bodźcowe wielu elementów meteorologicznych, może również być traktowany jako miernik kompleksowej oceny meteorotropowego działania atmosfery.

Jako sezon bioklimatyczny rozumie się tutaj okres w roku, w którym częstość pojawiania się poszczególnych typów międzydobowych zmian ciśnienia atmosferycznego lub ich charakterystyczny układ wykazuje specyficzne cechy, odmienne w stosunku do pozostałych okresów w roku (por. Woś 1977, 1996).

Na podstawie przyjętej procedury badawczej powstał obraz struktury sezonowej międzydobowych zmian ciśnienia atmosferycznego na obszarze Poznania (ryc. 10). Charakterystyczną cechą tej struktury są cztery sezony: A, B, C i D, spośród których dwa (B i C) notowane są dwukrotnie w ciagu roku, co wynika z naturalnego rytmu wielu elementów meteorologicznych, w tym także międzydobowych zmian ciśnienia.

Struktura częstości poszczególnych typów zmiany ciśnienia atmosferycznego w każdym sezonie wskazuje na zróżnicowany udział poszczególnych bodźców mechanicznych (ryc. 11).

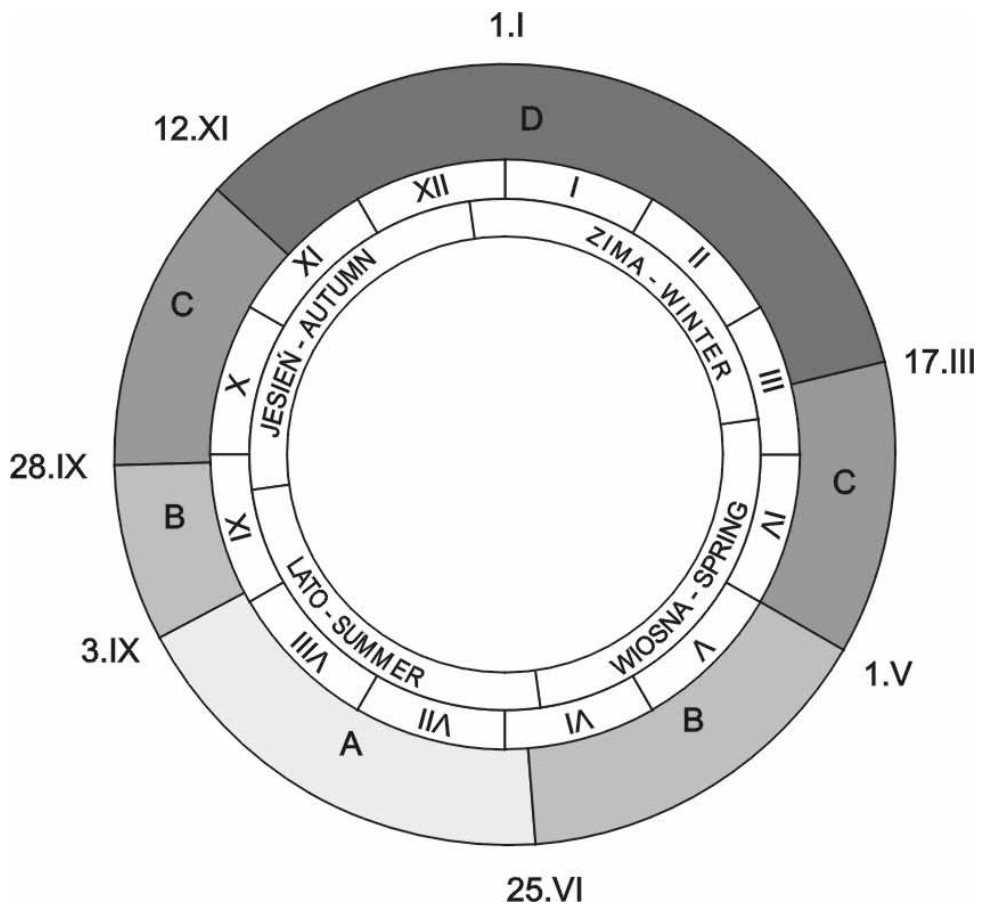

Ryc. 10. Sezony bioklimatyczne międzydobowych zmian ciśnienia atmosferycznego

(A, B, C, D) wyróżnione w rejonie Poznania oraz daty ich początku

Fig. 10. The bioclimatic seasons of the interdiurnal atmospheric pressure changes

(A, B, C , D) noticed in the area of Poznan and the dates of their beginnings 


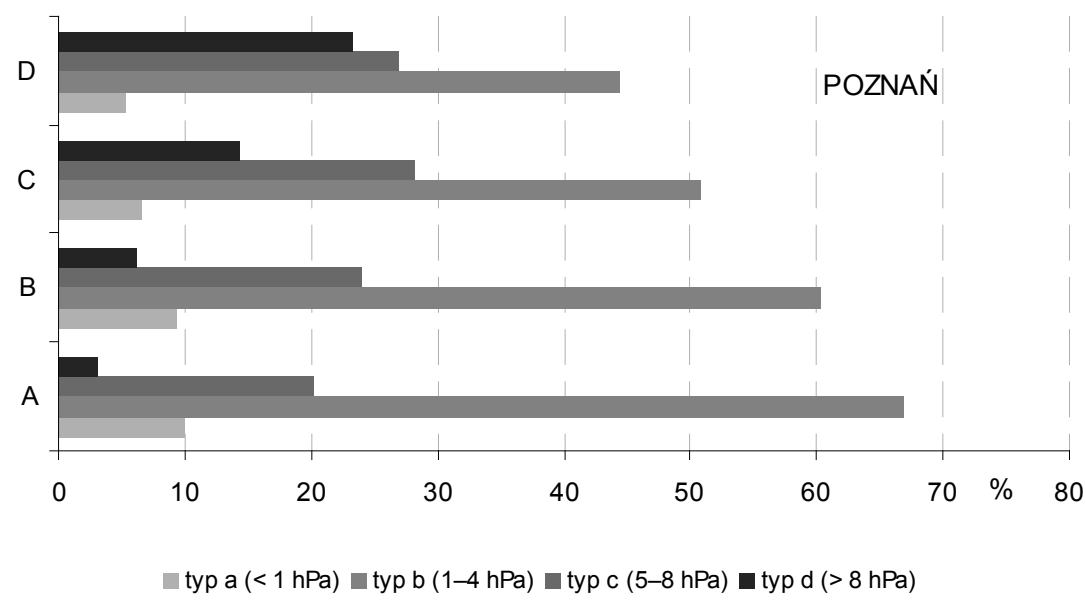

Ryc. 11. Poznań - średnia częstość typów zmian ciśnienia $(a, b, c, d)$ w wyznaczonych sezonach (A, B, C, D). Dane z lat 1951-2000 [\%]

Fig. 11. Poznan - the frequency of the days withe the particular types of pressure changes $(a, b, c, d)$ in distinguish bioclimatic seasons (A, B, C, D). Data from the years 1951-2000 [\%]

Sezon A pojawia się w Poznaniu w najcieplejszej części roku. Jego początek przypada niemal jednocześnie z nadejściem lata, natomiast koniec 2 września (tab. 2). Czas trwania tego sezonu to 70 dni, spośród których najczęściej notuje się dni ze słabym odczuciem międzydobowej zmiany ciśnienia typu $b(67 \%)$, $20 \%$ to dni z typem $c$ (umiarkowane odczucie), 10\% dni z typem $a$ (brak odczucia zmiany) oraz $3 \%$ dni z typem $d$ (silne odczucie zmiany ciśnienia).

Tabela 2. Poznań - daty początku i końca sezonów bioklimatycznych międzydobowych zmian ciśnienia oraz ich długość wyrażona liczbą dni

Table. 2. Poznan - the dates of the beginning and end of the bioclimatic seasons of the interdiurnal changes and their time of duration highlighted with the number of days

\begin{tabular}{cccc}
\hline Sezon & Data początku & Data końca & Czas trwania \\
\hline A & 25.06 & 02.09 & 70 \\
& 01.05 & 24.06 & 55 \\
B & 03.09 & 27.09 & 25 \\
& 17.03 & 30.04 & 45 \\
C & 28.09 & 11.11 & 45 \\
& 12.11 & 16.03 & 125 \\
\hline
\end{tabular}

Biorąc pod uwagę udział poszczególnych typów zmian ciśnienia w kolejnych latach badanego, okresu należy stwierdzić, że największej zmienności corocznej 
można spodziewać się w typach $a$ i $d$, natomiast z największą powtarzalnością coroczną występują typy $b$ i $c$.

Sezon B pojawia się dwukrotnie w roku (ryc. 10). Za pierwszym razem rozpoczyna się 1 maja, a kończy 24 czerwca (trwa 55 dni); natomiast drugi raz w roku pojawia się w ciagu 25 dni - od 3 do 27 września (tab. 2). Łącznie, podobnie jak w sezonie A, w obu okresach wystąpienia sezonu B odnotowuje się najwięcej dni ze zmianą ciśnienia typu $b$ (60\% dni). Dla tego sezonu zauważa się także podobną częstość dni z typem $a$ oraz większą z typem $c(24 \%$ dni) i typem $d$ (ok. 6\% dni). Świadczy to o większej bodźcowości sezonu B w porównaniu z sezonem A (ryc. 11). Z kolei zróżnicowanie z roku na rok pojawiania się dni z poszczególnymi typami zmiany ciśnienia mierzone współczynnikiem zmienności wskazuje, że największych odchyleń od wartości średniej należy spodziewać się w typach $a$ i $d$, znacznie mniejszych w typie $c$ i najmniejszych w typie $b$.

Sezon C jest drugim, który pojawia się dwukrotnie w ciagu roku (ryc. 10). Pierwsze jego wystapienie notuje się od 17 marca do 30 kwietnia, natomiast za drugim razem pojawia się z końcem września i trwa do drugiej dekady listopada (tab. 2). Za każdym razem sezon $\mathrm{C}$ pojawia się przez 45 dni, spośród których w sumie $51 \%$ to dni z bodźcami słabymi (ryc. 11), 7\% to dni z brakiem odczucia zmiany ciśnienia (w obu przypadkach mniej niż w poprzednich sezonach), natomiast dni z bodźcami umiarkowanymi stanowią 28\%, a dni z bodźcami silnymi niemal 15\% (w tych przypadkach znacznie więcej niż w sezonie A i B). Zmienność coroczna liczby dni z poszczególnych typów zmiany ciśnienia wykazuje również w tym sezonie najwyższe zmiany w typie $a$ i $d$ oraz najniższe w typie $b$ i c. Można stwierdzić, że sezon $\mathrm{C}$ odznacza się silniejszymi, w stosunku do wcześniej opisanych sezonów, bodźcami mechanicznymi.

Sezon D jest najdłuższym w roku sezonem międzydobowych zmian ciśnienia (ryc. 10). Występuje w okresie jesienno-zimowym i trwa przez 125 dni od 12 listopada do 16 marca (tab. 2). Na strukturę tego okresu w największym stopniu składają się, podobnie jak w pozostałych sezonach, dni ze słabym odczuciem zmian ciśnienia, które stanowią 45\% wszystkich dni (ryc. 11). W sezonie D najmniejszym udziałem wyróżniają się dni typu $a$ (brak odczucia zmiany ciśnienia) - niewiele ponad 5\%. Niemal $27 \%$ to dni z umiarkowanym odczuciem zmiany ciśnienia typu $c$, natomiast aż $23 \%$ stanowią dni z silnym odczuciem zmiany ciśnienia typu $d$. Za sprawą zmian ciśnienia o umiarkowanym i silnym odczuciu tej zmiany sezon D wyraźnie wyróżnia się spośród pozostałych jako najbardziej bodźcowy okres w ciągu roku. Badanie corocznej zmienności struktury udziału poszczególnych typów międzydobowych zmian ciśnienia wykazuje, podobnie jak w poprzednich sezonach, największe coroczne zróżnicowanie w typach $a \mathrm{i} d$, a także znacznie większą powtarzalność typów $b$ i $c$. 


\section{WNIOSKI}

Rezultaty badań dotyczące rocznej cykliczności międzydobowych zmian ciśnienia atmosferycznego potwierdzają wcześniejsze spostrzeżenia Kozłowskiej-Szczęsnej (1991) oraz Fortuniaka i współpracowników (2000). Stwierdzono również roczną cykliczność dni z poszczególnymi typami bodźców mechanicznych, wyraźną szczególnie w zakresie bodźców silnie odczuwanych przez organizm człowieka. Polega ona na występowaniu największych częstości tych dni w chłodniejszej części roku (z maksimum w zimie na poziomie przekraczającym 25\% wszystkich dni), a także niewielkich częstości w najcieplejszej części roku (w ciągu lata udział tych dni spada do 2-3\%). Z kolei roczne przebiegi częstości dni z brakiem odczucia zmiany ciśnienia i słabym jej odczuciem wykazują cykliczność objawiającą się najmniejszym ich udziałem w chłodniejszej i największym w cieplejszej części roku.

Badanie corocznej zmienności udziału dni z poszczególnymi typami zmiany ciśnienia w wieloleciu 1951-2000 wykazało, że z największą powtarzalnością pojawiają się typy $b$ i $c$; pozostałe $(a$ i $d$ ) wykazują znacznie większą zmienność.

Zanotowane trendy zmian - ujemny, w liczbie dni z typem $b$ (ponad 15 dni/100 lat), oraz - dodatni, w dniach z silnym odczuciem zmian ciśnienia typu $d$ (ponad $13 \mathrm{dni} / 100$ lat) - nie wykazały istotności statystycznej.

Wyznaczone sezony bioklimatyczne międzydobowych zmian ciśnienia wskazują na występowanie okresów o znacznie zróżnicowanym nasileniu bodźców mechanicznych. Najbardziej niekorzystnym okresem w roku, ze względu na największy udział silnych bodźców mechanicznych, jest najdłuższy, występujący w chłodniejszej części roku, sezon D. Z kolei najmniej bodźcowym sezonem, ze względu na najmniejszy udział silnych bodźców, jest sezon A, który pojawia się $w$ okresie letnim. Pomiędzy wspomnianymi sezonami się dwukrotnie w ciagu roku występnją dwa przejściowe sezony B i D, o mniejszej bodźcowości w stosunku do sezonu D i większej - do sezonu A.

\section{LITERATURA}

Bednorz E., Kolendowicz L., Bielec-Bąkowska Z., Bokwa A., Żelazny M., Kicińska B., Lewik P., Nowosad M., Ustrnul Z., 2001: Regionalizacje, typologie i sezony klimatyczne z zastosowaniem analizy skupień, Przegl. Geofiz., 48, 1-2, 9-30.

Chojnicki Z., Czyż T., 1973: Metody taksonomii numerycznej w regionalizacji geograficznej, PWN, Warszawa.

Fortuniak K., Kożuchowski K., Papiernik Ż., 2000: Sezonowa zmienność ciśnienia atmosferycznego w Warszawie w XIX i XX wieku, Przegl. Geofiz., t. 45, z. 1, 17-32.

Gabała J., 2004: Zastosowanie analizy skupień do wydzielania kompleksów pogodowych sprzyjajacych wystapieniu wysokich i niskich stężen zanieczyszczeń w Tarnowie. [W:] A. Bokwa,

Z. Ustrnul (red.), Zastosowanie wybranych metod w klimatologii, IGiGP UJ, 121-135.

Jarzyna K., 2004: Zastosowanie wybranych metod statystycznych w określaniu wplywu lokalnej 
i wielkoskalowej sytuacji meteorologicznej na warunki dyspersji zanieczyszczeń powietrza w Krakowie. [W:] A. Bokwa, Z. Ustrnul (red.), Zastosowanie wybranych metod w klimatologii, IGiGP UJ, 149-160.

Kolendowicz L., 1998: Zjawiska burzowe w Polsce a warunki synoptyczne, Bogucki Wyd. Nauk., Poznań.

Kozłowska-Szczęsna T., 1991: Antropoklimat Polski, Zesz. IGPZ PAN, nr 1.

Kozłowska-Szczęsna T., Błażejczyk K., Krawczyk B., 1997: Bioklimatologia człowieka. Metody $i$ ich zastosowanie $w$ badaniach bioklimatu Polski, Monografie IGiPZ PAN, 1.

Parysek J., 1982: Modele klasyfikacji w geografii, Wyd. Nauk. UAM, Poznań.

Tamulewicz J., 1982: Taksonomiczne podstawy typologii reżimu opadów atmosferycznych na przykladzie Pojezierza Pomorskiego i Niziny Wielkopolskiej, Dok. Geogr., 3-4.

Woś A., 1977: Zarys struktury sezonowej klimatu Niziny Wielkopolskiej i Pojezierza Pomorskiego, Wyd. Nauk. UAM, Poznań.

Woś A., 1996: Struktura Sezonowa Klimatu Polski, Bogucki Wyd. Nauk., Poznań. 